\title{
Urban Citizenship and the Spatial Encounter between Turkish Migrants and Syrian Refugees in Berlin
}

\section{„Urban Citizenship“ und räumliche Aushandlungsprozesse zwischen türkischen Migranten und syrischen Flüchtlingen}

https://doi.org/10.2478/rara-2019-0023

Eingegangen: 27. April 2018; Angenommen: 26. Februar 2019

\begin{abstract}
This article critically discusses how Turkish migrants as an established migrant group have interpreted and acted on the arrival of Syrian refugees in Berlin from 2015 onwards and whether their responses have resulted in new spaces in which new contestations and/or solidarities emerge. To this end, it focuses on the processes and the ways in which established groups (re-)articulate their urban citizenship and belonging to a particular urban space in relation to newcomers. Building on the analytical framework of relational and agency-centered articulation of urban citizenship and drawing on research data collected in the Kreuzberg and Neukölln neighborhoods of Berlin, the analysis has two main findings. Firstly, Turkish migrants have been involved in solidarity activities and contribute to a more inclusive urban citizenship regarding Syrian refugees. At the same time, they perceive Syrian refugees as a threat to their standing in the city and their right to the usage of urban space. This results in a more defensive urban citizenship against the refugees. Secondly, the unequal power relations and local, national and transitional dynamics act as intervening factors shaping Turkish migrants' responses to Syrian refugees and the process of urban citizenship formation.
\end{abstract}

Keywords: Berlin, urban citizenship, Turkish migrants, Syrian refugees, spatial encounter

Zusammenfassung: Dieser Artikel diskutiert kritisch, wie türkische Migranten als etablierte Gruppe ab 2015 die Ankunft syrischer Flüchtlinge in Berlin wahrgenommen und darauf reagiert haben und ob durch ihre Reaktionen neue Räume der Auseinandersetzung und/oder Solidaritäten entstanden sind. Zu diesem Zweck werden die Prozesse und die Art und Weise untersucht, in der etablierte Gruppen ihre „urban citizenship“ und ihre Zugehörigkeit zu einem bestimmten urbanen Raum gegenüber Neuankömmlingen artikulieren. Aufbauend auf dem analytischen Konzept der relationalen und akteurzentrierten Artikulation von „urban citizenship“ und Forschungsdaten aus den Berliner Stadtteilen Kreuzberg und Neukölln kommt die Studie zu zwei Hauptergebnissen. Erstens waren türkische Migranten in Solidaritätsaktionen eingebunden und haben zu einer integrativeren „urban citizenship“ in Bezug auf syrische Flüchtlinge beigetragen. Gleichzeitig haben sie syrische Flüchtlinge als Bedrohung für ihr Ansehen in der Stadt und ihr Recht auf Nutzung des städtischen Raums wahrgenommen. Dies führte zu einer defensiveren „urban

*Corresponding author: Dr. Burcu Togral Koca, Technische Universität Berlin, Institut für Stadt- und Regionalplanung, Fachgebiet Transfor-
mation städtischer Räume im internationalen Kontext, Hardenbergstraße 40 A, 10623 Berlin, Deutschland, E-mail: burcu_togral@yahoo.com

¿ Open Access. (C) 2019 Burcu Togral Koca, published by Sciendo. (G)BY-NC-ND This work is licensed under the Creative Commons Attribution-NonCommercial-NoDerivatives 4.0 License. 
citizenship“ gegenüber den Flüchtlingen. Zweitens wirken die ungleichen Machtverhältnisse und die lokale, nationale und transnationale Dynamik als intervenierende Faktoren, die die Reaktion türkischer Migranten auf syrische Flüchtlinge und den Prozess der Bildung von „urban citizenship“ beeinflussen.

Schlüsselwörter: Berlin, urban citizenship, türkische Migranten, syrische Flüchtlinge, räumliche Aushandlungsprozesse

\section{Introduction}

Since the eruption of the Syrian war in 2011, over five million people have fled violence and sought asylum mainly in neighboring countries such as Turkey, Jordan and Lebanon. In the meantime, European countries have been widely criticized for not sharing responsibility. With its historic decision to open its borders to refugees stuck in Hungary in the summer of 2015, only Germany (and Sweden) have followed a relatively "open door" approach towards Syrian refugees. In particular, Germany suspended the Dublin Protocol for Syrian refugees "by declaring all Syrian asylum-seekers welcome to remain in Germany - no matter which EU country they had first entered" (Hall/Lichfield 2015). Since then, Germany has received the highest number of first-time asylum applications in Europe in absolute terms and has become the most preferred destination for many Syrian refugees (Katz/Noring/Garrelts 2016: 3).

Regarding resettlement, refugees have been distributed among the 16 federal states (Länder) of Germany through the so-called Königstein quota system. States are accordingly allocated new refugee residents based on their capacity to resettle them, their tax revenues and current population. The city-state of Berlin, which comprises 12 residential districts, has accepted the highest number of refugees per square kilometer of all the German states (see Katz/Noring/Garrelts 2016: $11 \mathrm{f}$.). One of the most multicultural cities in Europe and home to diverse groups of migrants, Berlin has witnessed various changes and challenges since the refugees arrived. As in other cities like Munich and Hamburg, the first arrivals were welcomed by a large proportion of the public and supported by grass-roots movements. The city witnessed several public campaigns of solidarity and a host of civil society initiatives to facilitate integration. Rising numbers of refugees, however, also created new spaces of contestation especially in areas related to the labor market, housing, education, and so on.

Against this backdrop, this article analyzes how the established Turkish migrant community has interpreted and responded to the arrival of Syrian refugees in Berlin and whether their responses have prompted new patterns and relations of contestation and/or solidarity. ${ }^{1}$ Building upon the theoretical and conceptual framework of relational and agency-centered articulation of urban citizenship, it critically examines how/whether established migrant groups (re-) articulate their urban citizenship and belonging to a particular space through their encounter with newcomers, and whether this (re-) articulation transforms and challenges existing inclusion/ exclusion dynamics in the urban space. While numerous works have examined the relationship between Turkish migrants and urban regeneration, especially in the German context, their perceptions about other migrant groups have yet to be analyzed. Moreover, the implications of encounters between these two different migrant groups for the construction and meaning of (urban) citizenship have been mostly overlooked. Any attempt to close this gap requires making an "analytical distinction between Long-term residents and Newcomers [...] because the length of residence [...] represent[s...] a crucial factor" (Freiheit/Seidelsohn 2013: 13). As such, this article seeks to map out the complexities of migrant diversity and multiplicity of urban citizenships.

The article proceeds as follows. First, I outline the analytical framework, which is grounded in the relational and agency-based articulation of urban citizenship and combines elements from critical migration and urban studies. The next section is an outline of the methodology and data collection process. The third section offers a brief account of Berlin as an urban space of migration, followed by an empirical analysis of Turkish migrants' perceptions of and responses to Syrian refugees. The

1 Here, an important clarification is necessary. The terms "Turkish migrants" and "Syrian refugees" are both problematic in the sense that these labels presuppose the idea that migrants are the effects (in both senses) of the nation-states from which they have come. However, many of those originating from Turkey and Syria do not identify as either "Turk" or "Syrian", and are from a variety of ethnic and linguistic backgrounds. For example, many Turkey-origin migrants in Germany - whether guest workers or refugees - are in fact Kurdish speakers and identify as Kurdish. Similarly, many Syrian-origin refugees are Kurdish or identify as Arabic. With this discussion in mind, the article uses the terms critically in order to avoid the trap of "methodological nationalism". 
analysis elaborates further two different socio-spatial fields: spaces of solidarity and spaces of contestation. Two findings emerge as crucial. Firstly, the interplay between particular socio-economic, political, religious and ethnic characteristics of Turkish migrants shapes their social standing in urban space. Secondly, unequal power relations and local, national and transnational dynamics act as crucial intervening factors shaping urban-citizenship-making practices of Turkish migrants and their responses to Syrian refugees.

\section{A Relational and Agency- centered Articulation of Urban Citizenship}

A burgeoning literature has emerged in the recent decades critiquing certain basic tenets of established migration research, such as "nation-states as a unit of analysis", "liberal-democratic notion of citizenship" and "treating migrants as passive victims" (see, among others, Işın 2002; Castaneda 2012; Bork-Hüffer/Etzold/ Gransow et al. 2016). Asserting that such conceptualizations are the products of an unthinking "methodological nationalism" (Wimmer/Glick Schiller 2003) that reduces society to the nation-state as a unit of analysis, recent studies have sought to move beyond them. They do so by foregrounding the city as an important, if not primary, context in which institutional policies and migrant practices over space-making interact, producing diverse outcomes (Glick Schiller/Çağlar 2009; Kalandides/Vaiou 2012).

This shift in focus to the city has also triggered criticisms of the notion of national citizenship that limits migrant claim-making to legal rights and duties. According to critical migration and urban scholars, confining citizenship to the national level risks painting migrants as passive "victims trapped between an economic demand for their cheap labor and a political system that denies their rights" (Castaneda 2012: 71). Such a liberal-democratic notion of citizenship strips away migrants' agency to challenge or change political structures and policies (see Bork-Hüffer/Etzold/Gransow et al. 2016). Reflecting on the "gap between membership and substantive rights" and how discriminated groups mobilize for "recognition and equal rights" (Gebhardt 2016: 6), scholars explore practices "through which individuals and groups formulate and claim new rights or struggle to expand or maintain existing rights" (Işın/Wood 1999: 4). For example, in her study on guest worker mobilization in Europe, Soysal
(1994: 164) highlights how guest workers without formal citizenship rights have developed new "patterns of incorporation" transcending the "logic of national citizenship." Similarly, Castaneda (2012: 71 f.) shows that migrants may gain "de facto" citizenship status through their involvement in the labor market (formally or informally), by paying taxes, volunteering, working for governmental agencies or establishing organizations. This implies that citizenship practices include but are not limited to voting.

A rich literature has thus emerged probing into the connections between migration, urban citizenship and cities. This literature is based on an idea of citizenship as a social practice that enables migrants to act beyond the state through active local and transnational engagement (see Benhabib 1999; Ehrkamp/Leitner 2003) and to contribute to the regeneration of cities (Hillmann 2011; Çağlar/Glick Schiller 2018). Without discounting the role of national citizenship and establishing simplistic binary oppositions between migrants and the "native" population, a number of scholars adopt a relational and agency-centered approach to urban citizenship (see among others Ehrkamp/Leitner 2003; Varsanyi 2006; Cohen 2015; Cohen/Margalit 2015). Taking urban citizenship as a "socio-spatial institution" and as a "process" through which migrants and residents re-articulate and contest its meanings and practices (Cohen/Margalit 2015: 668), this approach allows us to trace the role of agency and practices of migrants and residents regardless of their formal citizenship status, unequal power positions, and local, national and transnational dynamics, all of which are important intervening factors shaping the (re-) articulation of urban citizenship relationally and hierarchically.

Inspired by Lefebvre's concept of the "right to the city", the agency-centered articulation of urban citizenship frames citizenship as intrinsically linked to local patterns of residence, belonging and community participation. As such, it grounds claim-making within and over a particular urban space (see Lefebvre 1996; Harvey 2012; Purcell 2014). Whether or not they are national citizens, those who inhabit urban space are considered to justly claim the right to urban space. In this context, this approach promotes "new formations and normative definitions of belonging" in urban space (Fenster 2010: 63). Urban citizenship as such refers to progressive and inclusionary acts striving to enhance residential rights for all inhabitants (Cohen/Margalit 2015: 667).

A group of scholars has taken these claims further, underlining the role of power positions and the heterogeneity of diverse groups in urban citizenship and space-making. Taking encounters between established groups and newcomers seriously, they problematize 
reductionist and taken-for-granted assumptions about international incoming groups as "homogenously poor, marginalized and powerless" (Smith/Guarnizo 2009: 619) and established residents as "a cohesive group of metropolitan 'haves"' (Cohen/Margalit 2015: 669). Instead, they tease out the contested nature of spaceand claim-making by various actors, who are "differently situated both spatially and temporally" (Cohen/Margalit 2015: 669; see also Ehrkamp/Leitner 2013). Such relational and agency-centered articulation of urban citizenship sheds light on "the ways in which city residents articulate their identities relationally and hierarchically against new and old 'others'” (Cohen/Margalit 2015: 666), given that urban space is political and formed by unequal power geometries (see Massey 2011). This throws into sharp relief questions of "who participates" and "power relations and power differentials that impact on the ability to participate in meaningful ways" in urban space (Kemp/Lebuhn/Rattner 2015: 707). As expressed further by Smith and Guarnizo (2009: 620 f.), "the question of 'inhabitance' is often fought out along the lines of who has the power to decide who is an established resident, legitimate local actor, or who is acceptable as a new resident and, thus, who has the right to local socio-political, cultural, and economic space and who does not." The rest of this article demonstrates different migrant groups have access to varying degrees of socio-economic and political capital, which produces hierarchies among and within them. In other words, not every migrant or resident is equally positioned to make claims to the city. These asymmetrical power relations create "tensions" over urban citizenship (Smith/Guarnizo 2009: 620) and contestations between different groups struggling over the same urban space.

Cohen (2015: $162 \mathrm{f}$.) explains the emergence of these tensions and spaces of contestation between newcomers and established residents within the so-called defensive urban citizenship framework, "whereby groups marginalized by the prevailing urban economic and identity regimes attempt to fend off threats to their localities and resources." In doing this, the established groups, who feel threatened both by structural factors and the practices of claim-making of newcomers, tend to develop a "reactive place-based identity" by raising urban boundaries and utilizing all the resources at their disposal, including "formal state and urban affiliations, ethno-racial and religious boundaries, as well as physical control over urban space" (Cohen 2015: $170 \mathrm{f}$.).

However, contestation may not be the only socio-spatial framework portraying encounters of different groups and their perceptions vis-a-vis each other within a spe- cific urban space. Taking urban citizenship as a process of "shifting alliances and antagonisms between groupings" (Painter 2005: 12), spaces of solidarities may also emerge between and within different groups of residents or migrants. In contrast to the defensive citizenship approach, newcomers may not be perceived as "contenders for scarce urban socio-political and economic resources" (Cohen/Margalit 2015: 669). Rather, they are likely to be perceived as valid members of the city with a legitimate right to actively be involved in and claim urban space, as the right-to-the-city approach promotes. In this context, independent of their power position in the city and sense of marginalization in socio-economic, political and cultural terms, a "left-wing" political orientation may feed into solidarities with "newcomers", claiming the right to the city for all (Cohen/Margalit 2015: 669.). Apart from this idealistic and normative understanding of belonging, shared or similar experiences and grievances can also lead to alliances and the mobilization of solidarities among diverse groups with different power positions in urban space (see Miller/Nicholls 2013). However, these kinds of individual or collective political identities may by themselves fall short of conveying an understanding of the processes at play shaping different forms of responses to the newcomers' incorporation into the urban space.

This brings us to the role of "intricate local, national and transnational interconnections" that shape urban-citizenship-making practices and negotiations between different groups of residents over residential claims (Ehrkamp/Leitner 2013: 129). Scholars with a relational and agency-centered perspective on citizenship draw attention to exclusionary/inclusionary dynamics imposed by local and national policies. In other words, states' power to shape national citizenship models, integration policies and urban policies are all important as "socio-political and physical conditions of spaces [that] frame [migrants'] livelihoods, opportunities, and agency" (Bork-Hüffer/Etzold/Gransow et. al. 2016: 128). For example, national citizenship models and discourses not only condition migrants' legal, social and political rights and opportunities, but also "the frameworks, key terms, metaphors, and language of immigration debates, and the representation of immigrants in the social imaginary" (Çağlar 2001: 602). Similarly, the political agency of any resident - whether a migrant or "native" - cannot be disconnected from the existing urban regime, its participatory dynamics and instruments or its socio-economic, political and cultural fragmentations. To put it differently, migrants' ability and their interaction with other groups and actors are conditioned by political opportunity 
structures that greatly influence "migrant identities and their patterns of organization and political participation" (Koopmans 2004: $451 \mathrm{f}$.). Hence, any analysis exploring the role of migrants or residents in city making has to consider the specific political structures and urban regimes in which they operate (see Kemp/Lebuhn/Rattner 2015).

Furthermore, migrants' transnational ties and connections to their "homelands", which are sustained with the help of developments in transport and communication (Koopmans, 2004: 5) should also be taken into account in exploring the migrants' urban citizenship claims and practices. As underlined by Glick Schiller and Meinhof (2011: 25), migrants' practices are shaped by transnational fields and "networks of networks, linking [them] to the institutional structures of more than one state." This transnationality results in "multiple sources and dynamics of migrant agencies, socialites and belongings" that are implicit in the migrants' claim-making in urban space (Çağlar 2016: 953).

\section{Methodology}

In the initial phase of the research, I collected secondary sources through archival research, mainly written works, and information provided by governmental authorities and Non-Governmental Organizations (NGOs), in order to build a contextual analysis. The second phase of the research involved fieldwork. Firstly, following the logic of non-participant observation, the data were gathered in the Berlin neighborhoods of Kreuzberg and Neukölln, which host a significant number of Turkish migrants and Syrian refugees. I also participated in the activities and meetings of Turkish migrants and their organizations. During these observations, informal discussion with migrants contributed greatly to data collection and provided me with valuable, first-hand information on migrants' experiences and perceptions and the impacts of institutional policies on their lives in urban space.

Secondly, focus groups and semi-structured interviews were conducted with Turkish migrants, representatives/members of their organizations and politicians of Turkish and Kurdish background to understand how they have interpreted and acted on the arrival of Syrian refugees. More precisely, 40 semi-structured interviews were conducted in Neukölln and Kreuzberg between March 2017 and February 2018. Interviewees included all four generations of migrants, including former guest workers, their children and grandchildren, refugees, and those who came as students and later settled in Berlin. It should be noted that the interviewees were chosen both purposefully and via the snowball method, taking the fact that migrants are differentially positioned in the social, cultural and political life of the city according to their gender, class, legal and ethnic/religious affiliation. Furthermore, interviewees came from different occupations with different levels of educational attainment and socio-economic capital, such as politicians, dönerci, a lawyer, a journalist, factory workers, business people and retired migrants.

Interviews were also conducted with migrant organizations for two reasons. First, they provided useful information to understand the general framework about how migrants view their participation in the city and what kind of responses they develop towards other groups. Second, "associations can be crucial in channeling immigrant discontent by voicing immigrant needs, making collective political claims, combining efforts, and dissipating discontent and alienation - even when they fail to obtain all of their explicit demands" (Castaneda 2012: 57). Organizations interviewed included religious associations (such as Sunni and Alevi groups), political parties from across the spectrum, including the Social Democratic Party (SPD), the Greens, the Left and the Christian Democratic Union (CDU), economic and social organizations, and organizations promoting the rights of certain disadvantaged groups, such as migrant women and refugees. The two focus group interviews were conducted with male and female migrants from Turkey. They were recruited through Kreuzberg and Neukölln-based Turkish NGOs that provide services to Turkish migrants. Both in the semi-structured interviews and focus groups, confidentiality and anonymity were underlined. Consistent with the standard techniques of analyzing interview data, common themes and patterns were identified and interpreted in accordance with the analytical framework. During the interviews, every effort was made to avoid suggesting or presuming any particular views, allowing migrants maximum space to voice their own experiences and concerns as they interpret them.

\section{Berlin, Migrants and Urban Regeneration}

\subsection{Turkish Migrants and Changing Neighborhoods}

Since the signing of a labor recruitment agreement between (West) Germany and Turkey under the "guest worker" system, Turkish migrants have contributed to 
the regeneration of Berlin, where they form the largest migrant group and the largest Turkish community outside Turkey. In particular, they have led to the emergence of new political, economic and social spaces by their socio-economic, cultural and political practices. These spaces were first experienced in Kreuzberg and Neukölln, former West Berlin neighborhoods, as many first-generation migrants from Turkey settled there from the beginning. This was mainly because in these neighborhoods, "much of the housing was dilapidated and lacked modern conveniences, rent was cheap. There was less competition from Germans and less discrimination by landlords" (Kil/Silver 2006: 97; see also Huning/ Schuster 2015). Since then these two neighborhoods have become a new "home" for Turkish migrants. As they settled in and established businesses including cafés and restaurants, they started to transform the urban space. They formed their own political, social and economic organizations as well as places of worship. Educational attainment has also gradually improved, with the share of migrants working in professions growing and a considerable urban business elite emerging (see Kil/ Silver 2006).

This process reached a certain critical mass of visibility once Turkish migrants decided that they were no longer "guests", but rather permanent residents. Various interviewees noted that at first migrants and their organizations oriented their activities towards Turkey. But after it became apparent that most of them would never permanently return to Turkey, some organizations re-oriented their focus almost entirely to local questions of justice, working for a range of marginalized and discriminated groups, including other immigrants and refugees, women, Jewish people, the unemployed and the lesbian, gay, bisexual and transgender community. These organizations partake in politics and the social life of the city. They contest discrimination and exclusion because they acknowledge they have the political power (read: political agency) to affect real change. This suggests that Turkish migrants have "improved" their power position in the city, and engage in claim- and space-making through their practices and beyond their formal citizenship status.

Despite these achievements, all interviewees pointed to ongoing obstacles to participation and claim-making. The most important factor mentioned was the failure of national migration policy to incorporate Turkish migrants into German society. Germany's belated acceptance of being an immigration country and the resulting indifference to the problems and situation of migrants were the most frequently cited issues. The enduring impact of the "guest" discourse, on both sides, has been a driving element in this context, according to the interviewees. They also emphasized that a lack of dual citizenship rights has prevented them from fully engaging in political life and from developing a feeling of belonging in Germany, despite their formal and informal practices. These accounts show the role of national citizenship status and policies over their claim-making. It is the everydayness of exclusion that is mainly underlined by interviewees. Ongoing discrimination and racism experienced in every sphere of life - ranging from employment to education to housing - were defined as the important reasons that have hampered their inclusion in the urban fabric. The words of the interviewee from the Left Party summarizes all these problems as follows: "we, as Turks or Kurds, have had to struggle with discrimination not only by law but in social life: in cafés, bars, schools, while looking for an apartment, in the workplace, in parliament, with police. Despite having citizenship rights, you have the feeling that you are not equal to Germans." Furthermore, the transnational dynamics and identities of Turkish migrants challenge their ability to contribute to urban space-making. All interviews referred to the religious, ethnic and political divide as a crucial factor preventing them from forming a collective force to defend their rights in the city.

Last but not least, interviewees noted that the neoliberal transformation of urban space in Berlin has also limited the extent to which they practice their right to urban space and advance claims accordingly, leading to socio-spatial marginalization. Gentrification in Kreuzberg and Neukölln, with the rise in rents that inevitably follows, is a central element here. Previously condemned as "slums" and "criminal hotspots", now both neighborhoods are highly popular with "new Berliners", including young professionals, middle-class families, artists and investors (Lebuhn 2015: 106). This is especially true for Neukölln, which for a long-time was home to a high percentage of migrants of Turkish, Kurdish and Arabic origin, and was characterized by "social marginality and spatial disadvantages [...] and a negative image in the eyes of both residents and outsiders" (Freiheit/Seidelsohn 2016: 80). As expressed by all interviewees, gentrification and the ensuing gap that has arisen between long-term rental agreements and new contracts, have led some to move elsewhere where rents are more affordable. The privatization of public housing units, together with the rising number of households, has exacerbated this and has seen rents rise in Berlin more than in almost any other German city (Holm 2013: 174). One interviewee who has been active in local institutions and in the housing sector noted: "The ongoing gentrification 
process reflects the demands of the market. This has not been a conscious move aimed at expelling Turkish migrants from Kreuzberg and Neukölln. At the beginning, for example, Kreuzberg was a place near to the Wall, full of the ugliest houses where nobody wanted to live. However, later, the neighborhood was modernized and became a central and popular district."

This transformation reflects how urban citizenship is played out relationally and hierarchically. Through the practices of urban citizenship, Turkish migrants have made these neighborhoods attractive places. While at the same time, as Castaneda (2012: 72) argues, "the ultimate benefits are often enjoyed by others who have a legal right to the city, access to highly paid jobs, and some leisure time to consume the new and increasingly expensive and exclusive services."

Berlin has introduced policy mechanisms to tackle these issues. From the beginning of the 1990 s, certain programs were introduced to fight social and economic marginalization. The most important was the Social City Program agreed in 1999 between the federal government and the states, targeting so-called disadvantaged districts, like Kreuzberg and Neukölln. Focusing on developing solutions to unemployment, limited access to education, social exclusion and marginalization, the program established neighborhood management offices - the so-called "quartier managers" (QM) - to coordinate the activities of the local municipal actors and stakeholders. These offices aim to support civic participation in decision making through a neighborhood council, an elected body of local representatives consisting of residents (rather than citizens), businesses and institutions (schools, associations, cultural centers, sometimes police), that takes decisions about how to use the neighborhood fund (Kalandides/Vaiou 2012: 257). In addition, Berlin's official Handbook of Participation details the instruments and policies of encouraging local residents' and actors' involvement in urban space-making and "democratization of city making" through bottom-up participation of residents and neighborhood groups (Kemp/Lebuhn/Rattner 2015: 710). These instruments are believed to provide migrants with an opportunity to participate in public decisions that affect their lives (Kalandides/Vaiou 2012: 257). One of the interviewees from a Neukölln-based Alevi organization stated: "We would like to raise our voices here. That is why we have become involved in the projects of the QM to introduce ourselves and our neighborhoods. We aim at integrating here both socially and culturally. We live here and we have to integrate here. However, for us, integration does not refer to assimilation; it means participation."
However, for others, success has remained limited. As underlined by Freiheit and Seidelsohn (2016: 78), these initiatives do not respond to the structural sources of social inequality but provide only a means to deal with the symptoms that arise therein. This point was also expressed by a long-term employee of a quartier management, who I interviewed: "Theoretically, it is a social democratic idea. But when it comes to the implementation and outcome of this program, I can say that it does not touch upon real structural problems. Why are there so many poor people living in this area, why do children in these neighborhoods remain in poor conditions or uneducated? How can this poverty be reduced? But without this program, what would happen? This is my justification. For ten years, I have been working here and I have been trying to justify my position arguing that at least there is such a program; otherwise nobody would care about these neighborhoods."

\subsection{Refugees Welcome?}

As mentioned, Germany in general and Berlin in particular witnessed unexpected levels of arrivals in the summer of 2015 and became the scene of mass solidarity campaigns and initiatives. But at the same time, the arrivals created various problems about the registration, accommodation and education of refugees. Grassroots refugee rights movements or the so-called welcoming initiatives arguably filled the gap between the ability and resources of state agencies and the scale of the problems (see Katz/Noring/Garrelts 2016; Mayer 2018). These initiatives organized various solidarity campaigns, sought donations, and provided refugees with food, clothes, legal counsel, and German classes. Hundreds of volunteers from different backgrounds with diffuse social status relating to age, gender, class, religion, ethnicity and educational level engaged in these solidarity endeavors. Turkish migrants and their organizations also engaged in support of the refugees. However, this initial welcoming culture seems to have reached its limit. The interviewees highlighted two events in 2016 - the alleged involvement of Syrians in sexual assaults at New Year celebrations in Cologne and the terrorist attack at Berlin's Christmas market conducted by a Tunisian national whose application for asylum had been rejected - as significantly weakening this "welcoming culture." An interviewee stated: "People have come to think that these refugees are coming here and killing us; then the question becomes, 'Why should I help them'?" 
At the same time, national and local refugee policies have been revised in response to these mass arrivals. Germany is a federal state and within this system Berlin has a distinct status (alongside Hamburg and Bremen) as a Stadtstaat (city-state). For this reason, Berlin's mayor doubles as the Ministerpräsident (minister-president) of the state. Each state has its own budget and autonomy in key policy areas. Regarding migration, and especially the accommodation of refugees, the states formulate and implement their own housing, health, education, language, vocational training and labor market integration policies. They define the terms for access to social services. Berlin, for example, has emphasized integration programs, including language and orientation courses, and vocational training since the Syrian refugees arrived. Currently, attendance at these courses for Syrian refugees is compulsory at the federal level as well. Additionally, since the 2016 amendments to the federal refugee law, refugees have been able to access work rights sooner, now three months after their registration. These changes are well explained by one of the representatives of the biggest Turkish NGO: "The central problem has been Germany's delayed acceptance that it has become an immigration country. This has been reflected in integration policies. However, recently there have been improvements in this field. Now, for example, the state provides language and job training courses and more employment opportunities. These are still not enough. These opportunities were not offered to first-generation Turks but were developed specifically for Syrians. For example, when Turkish migrants first arrived, there were no language courses. Currently, language courses are compulsory for Syrian refugees. In this sense, the German state has learned the lessons from the past failures of integration."

Yet, certain restrictions have also been put in place in the face of increasing arrivals of Syrian refugees. Among many obstacles that have prevented the Syrians from receiving asylum in Germany are the reintroduction of the Dublin System ${ }^{2}$, the temporary border controls with Austria and restrictions on family reunification. Interviewees also noted that they were left to cope with a lot of problems alone, including employment and accommodation. They have had to live in camps or sport halls for extended periods. Language problems and limited access to education prevented many from finding a job.

2 The Dublin System determines the member state responsible for examining asylum claims. Here, the responsible state is usually the first entry point or the so-called first country of asylum.

\subsection{Spaces of Solidarity}

Turkish migrants, individually or through their organizations and other grass-roots initiatives, engaged in solidarity work with Syrian refugees. In this respect, they promoted a more inclusive urban citizenship, calling for and defending the incorporation of refugees into the urban fabric as valid members. They developed "empathy with their concerns, struggles and sufferings" thereby building coalition with other civil society organizations and governmental authorities as well (Miller/ Nicholls 2013: 460). One organization member noted that the organization tries "to explain to Turkish migrants that we have had similar problems so we have the responsibility to help them and share our experiences with them." The supporters of the refugees belong to different age, income, occupation, education and gender groups, but among them left-wing groups and religious groups (both Alevi and Muslim) are more visible. Those with a refugee history were especially active in solidarity campaigns, drawing on their own experiences of forced migration to bond with newcomers.

In particular, their experiences with racism, marginalization and the failure of local and national integration policies appeared as underlying factors motivating their solidarity endeavors. As mentioned before, all interviewees stated that they had suffered discrimination and a lack of socio-economic and political rights in Germany. In this context, both migrants and the organizations (especially those with a leftist political orientation) expressed that they were in favor of a liberal refugee policy and long-term integration measures for Syrians. They also welcomed Merkel's "open door" approach. At the same, they were critical of Germany's restrictive migration policies and argued that the past failures which had prevented their incorporation should not be replicated in the case of the Syrian refugees. This is very well reflected in the words of one of the interviewees from a Turkish business association, who underlines his advocacy for social democracy: "Turkish organizations have backed Syrian refugees since they first arrived. We urged the authorities to protect their rights and demanded that new schools and language courses be opened. In other words, old failures should not be replicated. Now, Germans have tended to see them as temporary; however, we see them as permanent residents, not as guests. Maybe some of them will return, but I guess most of them will stay here. We think that they should not be deported; on the contrary, we have supported their integration here."

Turkish migrants' involvement was also seen as an important sign of their capacity to re-articulate their 
urban citizenship through their dealings with the issues impacting their lives in urban space. This can also be the expression of a sense of belonging to this very urban space. It further reflects how their power position in the urban space has transformed over time, implying that they became capable of voicing claims over who participates in the urban space as valid members. One of the interviewees who has worked at Turkish organizations for a long time noted: "This refugee incident has contributed to the involvement of the Turkish community in German politics. This is a historical turning point for the community here. For the first time, we have been assigned a duty. This actually shows that Turkish migrants are seen as part of this society. Now they are not only dealing with their own problems in Germany or Turkish politics, but they have become concerned about the problems of this society. Like German people, they have also been volunteering for refugees. It is also important in terms of the recognition of the Turkish community as an active political agent. The image of the Turkish community has improved not only in cultural terms but also in the functional context."

Some of these initiatives were short-lived, having offered only first-aid to the first arrivals in 2015. For example, a group of Turkish women from one of the mosques organized daily visits to the refugees staying in hangars and provided them with food and other required items. Other religious and non-religious organizations as well as volunteer groups collected donations and distributed foodstuffs, clothes and similar necessities.

There were also established and ongoing solidarity initiatives promoting long-term solutions with the aim of incorporating the refugees into the social fabric of the city. For example, they provided migrants with legal consultation, language courses and guidance for finding accommodation. They also conducted solidarity projects in cooperation with local and national authorities. For instance, one of the biggest Turkish organizations, TBB - Turkish Union in Berlin/Brandenburg v. Germany, which acts as an umbrella organization for almost 36 other Turkish organizations and defines its goal as supporting all Turkish migrants as well as other marginalized groups - conducted various projects and built solidarity networks. In cooperation with the Berlin Employment Agency, they organized an exhibition for vocational training in which various firms participated and offered young Syrian refugees with sufficient knowledge of German on-the-job training. More than 1,700 refugees attended this fair and around 200 refugees were placed in these firms.
Turkish migrants contributed to the incorporation of Syrians in the socio-cultural fabric of the city through social events and dinners. One of the interviewees working at a quartier management stated that: "Our projects have become successful in improving the neighborhood relationships among Turkish and Syrian people. They came together during certain social events such as dinners and sport organizations." Religious organizations, both Sunni and Alevi, organized regular meetings and dinners through which both groups have been able to get to know each other. However, their focus differs. Alevi organizations stated that they supported all refugees regardless of their religious and other ethno-national identities, arguing that their notion of democracy was based on universal justice, equality, and solidarity. Sunni organizations, however, mainly targeted Sunni Syrians on the basis of religious fraternity and ethnic-kinship.

Kurdish and Turkish politicians, especially from the Greens and the Left Party, have fought for the rights of refugees and raised their concerns in parliament. They were critical of the current policies. For example, the interviewee from the Left Party argued: "There is not a 'real' or sincere welcoming culture; rather there is the question of when they are going back to their homes. The idea is that they are guests and temporary here and following the end of the war, they have to go back to Syria. Three thousand refugees out of around one million already returned to Syria, either because they were not recognized as refugees and therefore sent back or the living conditions did not satisfy them or meet their expectations. On the one hand, Germany is trying to send these refugees back; on the other hand, it is trying to use them to fill labor shortages in certain sectors, such as health. So, there is no improvement in Germany's migration policy. The long-lasting failures and failed policies of integration have fed into the rise of anti-migrant sentiments and right-wing and populist parties."

Some of the interviewees also pointed out the institutional and bureaucratic problems impeding their solidarity efforts. For example, certain business organizations called on their members to hire the Syrian refugees in their respective sectors. One of them would like to engage in cooperation with the Federal Employment Agency to provide refugees with vocational training and employment opportunities. However, the interviewee from the Greens, who tried to establish such cooperation stated that their calls had not yet received an adequate response. Similarly, another interviewee from another business organization who was politically active for the rights of Turkish migrants said: "Our members 
mostly complain about bureaucratic hurdles in terms of employing foreigners. We called on the state authorities to simplify these bureaucratic procedures. For example, we have been asked to employ Syrian refugees. Even though we have members, especially in the furniture sector, employing refugees, this is not at a satisfactory level because of the bureaucratic challenges discouraging our members from doing so."

Another major challenge underlined by the interviewees is the current neo-liberal transformation and weakening of the welfare state. As mentioned above, the gentrification process and privatization of social housing were defined as crucial factors which have furthered the housing problem for all residents in Berlin. But, as the interviewee from the Greens noted, increasing rents together with a decreasing number of state-owned housing companies has hit the marginalized groups the hardest. Among migrants, refugees have been the worst affected due to their precarious economic and legal status which puts them in a disadvantaged position in the housing market. One of the interviewees stated that even though they have been helping the refugees to find accommodation, this was not an easy task. She further said that many non-camp refugees had to live in overcrowded flats to cover the rent. As newcomers, their insufficient networks limit their chances of finding accommodation as well. For example, during an informal talk with a Syrian refugee, he stated, "You, as a Turkish person, are in a more advantageous position in finding a flat because of the established networks among Turkish migrants." This illustrates the importance of existing social ties and being part of an established community for life chances and involvement in urban space, on the one hand, and the unequal and hierarchical access to residential rights, on the other hand.

Furthermore, the limited participatory channels and long-lasting discrimination Turkish migrants have faced were another factor impeding their involvement in the refugee issue in particular and in political life in general. They referred to the importance of formal citizenship rights in their participatory dynamics. The organizations also complain about the state's discriminatory attitude about funding. They argue that the German NGO projects are prioritized.

Another common theme, as underlined already and expressed by interviewees, is that Turkish migrants in Germany do not represent a homogenous group; rather, they diverge along various characteristics ranging from class to national, ethnic or religious origin. As some interviews illustrate, this heterogeneity has impeded common action in some areas, primarily concerning Syrian refu- gees. They complained that even when they wanted to organize solidarity actions in support of refugees, they could not come together due to ideological, ethnic and religious differences. They further emphasized the recent developments in Turkey and President Erdogan's policies towards the Turkish community here. They argue that as a result the community has become more polarized. This transnational factor impacts on their ability to be a collective political force in urban space and to promote a more inclusive urban citizenship.

\subsection{Spaces of Contestation}

The interviews also demonstrate widespread contestation and discontent among Turkish migrants about Syrian refugees. The main source of contestation was fears about loss of their socio-economic status. Viewed from the perspective of a defensive citizenship framework, Turkish migrants saw the refugees as a burden, rival or threat in the labor market, housing market and in education, or as "illegitimate" recipients of state benefits. The emergence of "'hierarchy-conflicts' about social positions, 'distribution-conflicts' about rare goods, employment, apartments, taxes etc., as well as 'rule-conflicts' about norms and values" (Freiheit/Seidelsohn 2013: 9) could be discerned. According to Huysmans, this also describes the securitization of certain groups that are considered a threat to security, the welfare state and the cultural identity of the "host" society (Huysmans 2006). This securitization process towards certain groups defined as risky "others" has become prominent following the rise of neo-liberalism from the 1980s onwards. These "others" have increasingly become the scapegoats for socio-economic problems, especially with a specific focus on the "threat" arising from "insurmountable" cultural differences (Balibar 1991).

Even though this securitization process depicts the representation of poor and Muslim migrants in the global North, the same hierarchical discourse is found among Turkish migrants in their dealings with Syrian refugees. As described by the interviewees, similar prejudices of Germans about Turkish migrants, now capture the latter's perceptions about Syrian refugees. As Cohen (2015: 170) eloquently argues, this is closely related to the long-lasting marginalization of (certain) Turkish migrants. For example, especially those working in unqualified jobs argued that the arrival of refugees might lead to an increase in already high unemployment rates among Turkish migrants. Also, they think that the state may limit the welfare benefits granted to them and 
instead allocate them to the refugees. Another underlying theme was the perception that Syrian refugees would abuse the welfare state. One interviewee, having come to Germany as a guest worker, commented: "Why did they come here? They should have stayed in Syria to fight for their homeland. They just seek to abuse the welfare state in Germany. I have seen many young Syrian refugees; they have money, they have iPhones that I do not have. They are living in luxury here."

A similar account was put forward by another retired guest worker: "What I have observed here is that those who are well-educated and in good economic situations have been able to come here. For example, I participated in solidarity campaigns of a Turkish organization and saw that they [the refugees] had worn luxury shoes and clothes in Syria; they did not like the shoes that we gave them. In my imagination, a person who flees war does not have any clothes, food or bread. [But this group] use iPhones. I think they abused the German state's aid."

In line with these perceptions, another point that was underlined by many interviewees is that Turkish migrants were "jealous" of Syrian refugees, as the latter were seen as more educated and qualified. One of the interviewees working on an integration course commented, "Many of them are engineers, nurses and doctors. And they have an incredible motivation to learn the language and they can learn so fast." In this context, they are seen as rivals and a threat to the power position of the Turkish migrants in the labor market.

However, despite these fears in the economic realm, especially in döner restaurants and construction sectors, a significant number of Syrian refugees have had to work informally under precarious conditions. One of the politicians stated, "I first heard this news in 2015, first I could not believe it, but it was true that Syrians have worked just for two Euros per hour at Turkish migrants' workplaces in Neukölln." Another interviewee stated, "I have an uncle who owns a kebab shop, and is informally employing two Syrian children." He further described this situation as a "master-slave" relationship. A second-generation retired Turkish immigrant noted similarly, "As I experienced personally, some Syrian refugees have been informally employed in the Turkish-run construction sector. They are provided only with meals and accommodation. They represent a flexible and cheap labor force. Last time, I met a Syrian electronic engineer who was previously a manager of a company but had to leave his wife and children in Syria. He is now working as a simple worker at a Turkish firm. I felt the pain in his eyes."

It was also alleged that Turkish organizations had taken economic advantage of Syrian refugees. It was underlined that some of the Turkish NGOs offered language courses, but they drew on funding from the state to do that. So, nothing has much changed for them. Indeed, they took advantage of this situation by receiving extra money from the state and supported their existing projects.

The increasing presence of Syrian refugees in Kreuzberg and Neukölln also furthered discontent among Turkish migrants. Indeed, the tension between Turkish migrants and the "native population" in these neighborhoods, which is closely linked to the neo-liberal transformation of urban space, has been complicated by the incorporation of a third group, Syrian refugees. As underlined by one interviewee, "due to the gentrification process especially following the fall of the Berlin Wall which made Kreuzberg and Neukölln attractive districts, German people did not want 'black heads' [Turkish migrants] residing in these places. There emerged a contestation and competition in housing markets in these districts. Now, Turkish migrants do not want Syrians to live in these neighborhoods, which are seen as belonging to them."

Similar accounts were put forward by a representative of a Neukölln-based NGO, who commented, "first Lebanese and now the Syrian refugees have been invading 'our' neighborhood and even pushing us out of our neighborhood through renting and buying apartments and opening up shops and restaurants." Another interviewee working in the housing sector commented that the privatization of state-owned companies has worsened the situation in the sector. He said, "With the arrival of the Syrian refugees, this problem has become more complicated. More social housing is needed. Turkish and Kurdish migrants have already experienced discrimination-related problems in the housing market. They think that their chances of finding accommodation would diminish with the arrival of Syrian refugees."

Regarding the education field, an interviewee contended that contestation better represents the situation. This interviewee has a consultation firm focusing on integration issues, and he stated that Turkish migrants were worried about overcrowded classes and the decreasing quality of education resulting from the presence of refugee children without any knowledge of German. This has also led to spatial differentiation between the two groups. As underlined by various interviews, educated Turkish migrants have already started leaving Neukölln and Kreuzberg in order to provide their children with better education opportunities. According to them, the arrival of Syrian refugees has intensified this process.

Another common tendency is the securitization and criminalization of Syrian refugees by linking them to ter- 
rorism, drug trafficking and violence. Especially for the secular section of Turkish migrants, Syrian refugees are conservative people who follow a radical interpretation of Islam. They even urge their children to avoid certain parts of Neukölln due to this so-called radicalization, which is perceived to be prompted by the arrival of the Syrian refugees. Similarly, there is a belief that the arrival of Syrian refugees increased crime rates. For Turkish migrants, Syrian refugees, who are mostly young and male, are involved in drug dealing and other petty crimes. The female interviewees also argued that the streets have become more dangerous for them (especially at night) because of Syrian men. During the focus group interviews with women, it was mentioned that Syrian men allegedly abused women and even physically attacked them on the streets. Even if the women had not themselves experienced such an incident, they believed that this could happen given the media reports of the so-called sexual harassment of women by Syrians in Cologne. Male interviewees also had similar accounts that many Syrian refugees were young and sexually inexperienced males, more prone to abuse women because of the liberal character of intersexual relationships in Germany.

Their transnational ties also play an important role in these perceptions. Rising anti-Syrian racism and hate speech have become salient in parallel with the numerous demonstrations and attacks against Syrian refugees that have occurred in Turkey. This anti-Syrian stance and the long-lasting anti-Arab sentiments in Turkey have influenced Turkish migrants' views regardless of their political orientation. Both leftists and nationalists referred to the so-called cultural incompatibility of Syrian refugees with the "German" and "Turkish" way of life. This culturalism based on the fabrication of cultural differences into a threat has taken much of its power from the homogenization and essentialization of culture and identity. In particular, according to one interviewee working with a number of NGOs, while most Turkish migrants have successfully integrated into German society, this would not be the case for Syrian refugees because of their cultural differences. He further argued that the German state would come to appreciate Turkish migrants in comparison, having seen how difficult it was for Arabs to integrate. Furthermore, Syrian refugees were seen as uncivilized, feudal, dirty, noisy and more prone to telling lies. One of the interviewees stated, "Ok, they have been fleeing the war, but Arabs in general and Syrian refugees in particular, are culturally so different from us. For example, eating food with one's hands is not compatible with my culture. Or they speak so loudly that it disturbs those in the vicinity. Syrian women wear burqas and refrain from contacting other men. This cultural difference bothers me a lot."

As part of these dynamics of contestation, there is also a degree of indifference implying an insufficient level of contact between the two groups. Indeed, some of the interviewees showed no interest in Syrian refugees at all. During the interviews, this was represented as a conscious attitude. One of the interviewees stated that he gave up going to a café where he had been a daily visitor for the past ten years. He said that "now Syrians have invaded this place." Also, the idea is that "we have to first deal with 'our' people and Syrian refugees are the responsibility of the German state" is another argument put forward by several interviewees. Similarly, this indifference was explained with a reference to a lack of infrastructure, including expertise, human resources and financial capacity. In their view, existing resources have to be used to incorporate "our" (i.e. Turkish) people.

Indeed, according to interviews, all these socio-economic and cultural problems are related to the German refugee policy, which they view as "too" liberal. Many of them blamed Angela Merkel for acting impetuously in this "refugee crisis", because, for them, these problems have intensified following the arrival of Syrian refugees. In line with this, another common theme that emerged in the interviews is that they had to struggle for a long time to achieve rights and the German state did not do anything for them. But now, according to them, Syrians have gained various rights without doing anything or contributing to society. Among these, language courses, employment rights and state benefits are the most noted.

\section{Conclusion}

Using a relational and agency-centered approach to urban citizenship, this article shows that Turkish migrants, as an established group, rearticulated and contested their urban citizenship and claim-making practices relationally and hierarchically vis-à-vis newcomers, namely, Syrian refugees. In this remaking of urban citizenship, Turkish migrants' spatial encounter with Syrian refugees and the ways in which the former responded to and acted on the arrival of the latter reveals the "multiplicity of urban citizenship(s), their variegated entitlements and the political process through which they are claimed, (re)-distributed, negotiated and secured" (Cohen/Margalit 2015: 670). Turkish migrants developed both inclusive and defensive urban citizenship discourses and practices against Syrian refugees, thereby 
showing the contested nature of urban citizenship-making constructed through a process of "shifting alliances and antagonisms between groupings" (Painter 2005: 12). As this research further demonstrates, this process is shaped by the interplay between the practices/agency of residents/migrants, their power positions and local, national and transnational dynamics, and gives rise to new spaces of solidarities and contestations.

First, regardless of their occupation, age, gender and education level, leftist leaning and politically active Turkish migrants have defended the incorporation of Syrian refugees into the urban space, as valid residents; hence they practice inclusive urban citizenship strategies. Religious groups also advocated solidarity campaigns on the basis of religious justifications. Apart from their political orientation and religious identities, shared or common experiences in relation to the problems of local or national policies and the neo-liberal transformation of urban space, both of which were described as jeopardizing their incorporation into urban space as equal residents, are the other prominent factors driving their solidarity with Syrian refugees. However, unequal power positions still inform these urban citizenship practices and the mobilization of solidarities among Turkish migrants. Benefiting from their established status and socio-economic and political capital, they managed to voice their claims over who participates in the urban space and thereby to challenge the exclusionary dynamics at a local scale. In other words, as established residents, they were able to utilize both the material and non-material resources at their disposal in order to reframe the boundaries of urban citizenship. Through these practices of claim-making, they indeed reasserted their urban citizenship.

However, the same power position and the "privileged" status arising from being established residents combined with their experiences and sense of marginalization, also fueled hostility among many interviewees towards Syrian refugees. Seeing Syrian refugees as a threat to their positioning in the urban space, these migrants drove spaces of contestation in the neighborhoods (which they often define as "theirs"). They also utilized exclusionary discourses about Syrian refugees and reproduced the hierarchical relationship vis-à-vis them in socio-economic, cultural and political fields. This contestation is prevalent particularly among the less educated interviewees working in unqualified jobs and living with state support and among former guest workers, even though some of these migrants defined themselves as "leftist" or adhered to cosmopolitan democratic values. This brings us to the framework of defensive urban cit- izenship. As argued by Cohen (2015: 171), "rather than simplistic racism or ethnic domination, this type of conduct is better understood within the context of a reactive place-based identity deployed by disenfranchised urban populations who - relegated to the lowest economic and identity echelons of urban society with little chance of ever moving up (or out) - resort to practices of resistance toward ethnic 'others' who are perceived to be infringing upon their modest turf."

Accordingly, it is the long-lasting failure of local and national policies which has fed the everyday discrimination and marginalization of Turkish migrants, and the neo-liberal transformation with its repercussions for social benefits, employment, housing and education that has heightened Turkish migrants' fears about Syrian refugees and contributed to a reactive place-based identity. On the part of Turkish migrants, competition over scarce resources emerged, which in turn has fed hostility towards newcomers, who are regarded as "outsiders" or "illegitimate recipients" of these benefits and services. Hence, following Cohen (2015: 170), it is right to suggest that Turkish migrants are "threatened' by both the neo-liberal order and the new transformation of their space through incoming migration."

On the other hand, well-educated Turkish migrants with the necessary economic means have also resorted to practices of defensive urban citizenship, aiming to "demarcate group boundaries in the face of Syrian refugees" (Cohen 2015: 171). They have engaged in spatial differentiation, for example, by moving into neighborhoods with better education opportunities or by refraining from encounters with Syrian refugees in other public spaces, such as cafes. Similarly, this unequal power position has manifested itself in the informal and precarious employment of Syrian refugees. In this context, these practices shed light on the relational and hierarchical formation of urban citizenship by established groups vis-à-vis newcomers, who do not have the necessary socio-economic capital to claim their rights over the usage of urban space. They further illustrate how structural forces, e.g. the (neoliberal) urban economy and exclusionary local/national migration policies, shape urban citizenship formations through creating new marginalized groups and spatial hierarchies.

Furthermore, as a crucial intervening factor, transnationality should be also taken into account when unpacking the process of remaking urban citizenship by Turkish migrants towards Syrian refugees. On the one hand, solidarity efforts were limited by migrant diversity especially in terms of political orientation and religious and ethnic background; this diversity remained intact because of 
transnationality and contributed to the polarization among Turkish migrants. On the other hand, long-established anti-Arab sentiments pertaining to the Turkish political and cultural landscape, which are coupled with current anti-Syrian sentiments, have structured the reactions of some of the Turkish migrants. Regardless of political orientation and ethnic or religious identity, these Turkish migrants have depicted Syrian refugees as culturally inferior, radical, violent and criminal. These prejudices have further contributed to exclusionary discourses and spatial differentiation, as expressed by female migrants who raised concerns over their physical security on the streets, and by others who complained about the "invasion" of public spaces and thereby refrained from spatial encounters with the refugees.

In sum, revealing the contested nature and multiplicity of urban citizenships, Turkish migrants' relational urban citizenship formation paved the way both for inclusionary and exclusionary dynamics. This forces us to rethink the conceptualization of urban citizenship, which mostly points to "progressive acts" striving to ensure "more dignified urban spaces for all inhabitants" (Cohen/ Margalit 2015: 667). As the defensive urban citizenship framework suggests, long-established groups can reassert their urban citizenship by creating new spaces of exclusion and spatial differentiation. Moreover, the research further demonstrates that while unpacking the formation of different urban citizenships, it is necessary to refrain from reductionist and simplistic categorizations of migrants and residents. Specific economic, social, political and cultural identities which lead to differential power positions in urban space do not by themselves explain the emergence of a particular urban citizenship (inclusive or defensive). Rather, markers of social identity, including class, religion, ethnicity and gender, have to be contextualized and interpreted through their interaction with local, national and transnational dynamics.

\section{References}

Balibar, E. (1991): Is there a 'Neo-Racism'? In: Balibar, E.; Wallerstein, I. (eds.): Race, Nation, Class: Ambiguous Identities. London/New York, 17-28.

Benhabib, S. (1999): Citizens, Residents, and Aliens in a Changing World. Political Membership in the Global Era. In: Social Research 66, 3, 709-744.

Bork-Hüffer, T.; Etzold, B.; Gransow, B.; Tomba, L.; Sterly, H.; Suda, K.; Kraas, F.; Flock, R. (2016): Agency and the Making of Transient Urban Spaces: Examples of Migrants in the City in the Pearl River Delta, China, and Dhaka, Bangladesh. In:
Population, Space and Place 22, 2, 128-145. doi: 10.1002/ psp. 1890

Castaneda, E. (2012): Urban Citizenship in New York, Paris, and Barcelona: Immigrant Organizations and the Right to Inhabit the City. In: Smith, M.P.; McQuarrie, M. (eds.): Remaking Urban Citizenship: Organizations, Institutions, and The Right to the City. New Brunswick/London. 57-79.

Çağlar,A. (2001): Constraining metaphorsandthetransnationalisation of spaces in Berlin. In: Journal of Ethnic and Migration Studies 27, 4, 601-613. doi: 10.1080/13691830120090403

Çağlar, A. (2016): Still 'migrants' after all those years: foundational mobilities, temporal frames and emplacement of migrants. In: Journal of Ethnic and Migration Studies 42, 6, 952-969. doi: 10.1080/1369183X.2015.1126085

Çağlar, A.; Glick Schiller, N. (2018): Migrants and City-Making: Dispossession, Displacement, and Urban Regeneration. Durham.

Cohen, N. (2015): Southern Discomfort: Defensive Urban Citizenship in Tel Aviv. In: Matejskova, T.; Antonsich, M. (eds.): Governing through Diversity. Migration Societies in PostMulticulturalist Times. London, 161-180. doi: 10.1007/978-1-13743825-6

Cohen, N.; Margalit, T. (2015): 'There are Really Two Cities Here': Fragmented Urban Citizenship in Tel Aviv. In: International Journal of Urban and Regional Research 39, 4, 666-686. doi: 10.1111/1468-2427.12260

Ehrkamp, P.; Leitner, H. (2003): Beyond National Citizenship: Turkish Immigrants and the (RE)Construction of Citizenship in Germany. In: Urban Geography 24, 2, 127-146. doi: 10.2747/0272-3638.24.2.127

Fenster, T. (2010): The Right to the City and Gendered Everyday Life. In: Sugranyes, A.; Mathivet, C. (eds.): Cities for All. Proposals and Experiences towards the Right to the City. Santiago, 63-76.

Freiheit, M.; Seidelsohn, K. (2013): Group $\square$ focused Enmity in the Locality: Perspectives on Conflicts in a Changing Neighborhood. Presented at the RC 21 Conference 2013, Resourceful Cities, Humboldt University Berlin. http://www. rc21.org/conferences/berlin2013/RC21-Berlin-Papers-3/13Freiheit-Seidelsohn.pdf (11.01.2019).

Freiheit, M.; Seidelsohn, K. (2016): Perspectives on conflicts and potentials in a changing neighbourhood: Berlin-Neukölln and the role of urban governance. In: Sirkeci, I.; Cohen, J.H.; Yazgan, P. (eds.): Conflict, Insecurity and Mobility. London, 77-88.

Gebhardt, D. (2016): Cities and immigrant citizenship: A comparison of local citizenship policies in Barcelona and Munich. Barcelona. = GRITIM-UPF Working Paper Series 26.

Glick Schiller, N.; Çağlar, A. (2009): Towards a Comparative Theory of Locality in Migration Studies: Migrant Incorporation and City Scale. In: Journal of Ethnic and Migration Studies 35, 2, 177202. doi: $10.1080 / 13691830802586179$

Glick Schiller, N.; Meinhof, U.H. (2011): Singing a New Song? Transnational Migration, Methodological Nationalism and Cosmopolitan Perspectives. In: Music and Arts in Action 3, 3, 21-39.

Hall, A.; Lichfield, J. (2015): Germany opens its gates: Berlin says all Syrian asylum-seekers are welcome to remain, as Britain is urged to make a 'similar statement'. In: The Independent, August 24, 2015. 
Harvey, D. (2012): Rebel Cities. From the right to the city to the urban revolution. London.

Hillmann, F. (Hrsg.) (2011): Marginale Urbanität. Migrantisches Unternehmertum und Stadtentwicklung. Bielefeld.

Holm, A. (2013): Berlin's Gentrification Mainstream. In: Bernt, M.; Grell, B.; Holm, A. (eds.): The Berlin Reader. A Compendium on Urban Change and Activism. Bielefeld. 171-188.

Huning, S.; Schuster, N. (2015): 'Social Mixing' or 'Gentrification'? Contradictory Perspectives on Urban Change in the Berlin District of Neukölln. In: International Journal of Urban and Regional Research 39, 4, 738-755. doi: 10.1111/14682427.12280

Huysmans, J. (2006): The Politics of Insecurity. Fear, Migration and Asylum in the EU. London.

Işın, E.F. (2002): Being Political: Genealogies of Citizenship. Minneapolis

Işın, E.F.; Wood, P.K. (1999): Citizenship and Identity. London.

Kalandides, A.; Vaiou, D. (2012): 'Ethnic' neighbourhoods? Practices of belonging and claims to the city: In: European Urban and Regional Studies 19, 3, 254-266. doi: 10.1177/0969776412438328

Katz, B.; Noring, L.; Garrelts, N. (2016): Cities and Refugees: The German Experience. Washington, DC.

Kemp, A.; Lebuhn, H.; Rattner, G. (2015): Between Neoliberal Governance and the Right to the City: Participatory politics in Berlin and Tel Aviv. In: International Journal of Urban and Regional Research 39, 4, 704-725. doi: 10.1111/14682427.12262

Kil, W.; Silver, H. (2006): From Kreuzberg to Marzahn: New Migrant Communities in Berlin. In: German Politics and Society 24, 4, 95-121.

Koopmans, R. (2004): Migrant mobilisation and political opportunities: variation among German cities and a comparison with the United Kingdom and the Netherlands. In: Journal of Ethnic and Migration Studies 30, 3, 449-470. doi: 10.1080/13691830410001682034

Lebuhn, H. (2015): Neoliberalization in Post-Wall Berlin. Understanding the City through Crisis. In: Critical Planning 22, 99-118.

Lefebvre, H. (1996): The right to the city. In: Kofman, E.; Lebas, E. (eds.): Writings on cities. Oxford, 147-159.

Massey, D. (2011): For Space. Los Angeles.

Mayer, M. (2018). Cities as sites of refuge and resistance. In: European Urban and Regional Studies 25, 3, 232-249. doi: 10.1177/0969776417729963

Miller, B.; Nicholls, W. (2013): Social Movements in Urban Society: The City as a Space of Politicization. In: Urban Geography 34, 4, 452-473. doi: 10.1080/02723638.2013.786904

Painter, J. (2005): Urban citizenship and rights to the city. Project Report. International Centre for Regional Regeneration and Development Studies. Durham.

Purcell, M. (2014): Possible Worlds: Henri Lefebvre and the Right to the City. In: Journal of Urban Affairs 36, 1, 141-154. doi: 10.1111/ juaf. 12034

Smith, M.P.; Guarnizo, L.E. (2009): Global Mobility, Shifting Borders and Urban Citizenship. In: Tijdschrift voor Economische en Sociale Geografie 100, 5, 610-662. doi: 10.1111/j.14679663.2009.00567.x

Soysal, Y.N. (1994): Limits of Citizenship: Migrants and Postnational Membership in Europe. Chicago.
Varsanyi, M.W. (2006): Interrogating "Urban Citizenship" vis-à-vis Undocumented Migration. In: Citizenship Studies 10, 2, 229249. doi: $10.1080 / 13621020600633168$

Wimmer, A.; Glick Schiller, N. (2003): Methodological Nationalism, the Social Sciences, and the Study of Migration: An Essay in Historical Epistemology. In: International Migration Review 37, 3, 576-610. doi: 10.1111/j.1747-7379.2003.tb00151.x 